\title{
Analysis of Factors Affecting the Sustainability of Elbahi Micro-Dam Catchment, Near Jigjiga Town, Ethiopia Somali Regional State, Ethiopia
}

\author{
Yohannes Gerezihier Gebremedhin ${ }^{1 *}$, Tsegay weldu ${ }^{2}$ and Aklilu bajgo ${ }^{1}$ \\ ${ }^{1}$ Department of Natural Resources Management, Ethiopia \\ ${ }^{2}$ Department of Water Resources and Irrigation Engineering, Ethiopia
}

Submission: November 11, 2018; Published: December 14, 2018

*Corresponding author: Yohannes Gerezihier Gebremedhin, Department of Natural Resources Management, Ethiopia

\begin{abstract}
Construction of micro dams to harvest the available surface water resources of dry land area is inevitable. Elbahi micro-dam is located near to Jigjiga town in Ethiopia Somali Regional state; it was constructed from 1986-1993 with multi-purpose dam to serve the community as a source of water supply for irrigation, domestic and livestock consumptions, and to protecting Jigjiga town from flood problems. Elbahi-micro dam watershed has bi-modal rainfall distribution. The larger amount of mean monthly precipitation of Elbahi-micro dam watershed received during the main rainy season which extends from March to May while the second rainy season when lesser amount of mean monthly precipitation received extends from July to September. The mean annual precipitation in Elbahi micro dam watershed is estimated as 550.1mm. The major soil classes in the Elbahi micro-dam watershed are; Dystric nitisols (48\%), Vertic cambisols (50\%) and chromic luvisols (2\%), which affect soil degradation differently. land use land cover of the study area shows the presence of five class's; shrub land (1.87\%), grassland (19.60\%), bare land (1.33\%), cultivated land (76.7\%) and urban land (0.5\%). range of slope; in the area has 4 scale ranges; 0-5 \%-upper part of the watershed which shews gentle and flat slope, 6-10\%, 11-20\% and 21-30\% in the lower part of the watershed to the left side (chena-ksen) of the catchment. This implies that the Elbaih-micro dam is prone to sedimentation, loss of the reservoir capacity, and the sustainability is under question.
\end{abstract}

Keywords: Elbahi Micro-Dam; Ethiopia Somali Region; Factors Affecting; Sustainability; Watershed

\section{Introduction}

As stated by Gleick [1], Kundzewicz [2], and Vorosmarty [3] freshwater scarcity is a global problem that is particularly acute in dryland, and that threatens the potential of agriculture to alleviate poverty and improve human health. In addition to the erratic nature of rainfall in dry land areas, extended drought also results in famine. Many dry land areas experienced unexpected excessive rainfall that can cause flash floods and consequently, loss of life and property. Dry lands (arid and semi-arid areas) are characterized not only by low annual precipitation, but also by its temporal and spatial variability Elbahi micro-dam is the one and found at Jigjiga woreda, Ethiopia Somali Regional state. Its construction was started around 1986 and finalized around 1993. Elbahi micro-dam was built by the fund obtained from EWWCE (Ethiopian Water Works Construction Enterprise) and Italy through UNDP (United Nation Development Program). Basically, it was constructed as a multi-purpose dam to serve the community as a source of water for irrigation and water supply for domestic and livestock consumptions. Although these objectives were not fully met, the dam has been serving Jigjiga town's community found in the downstream side, by protecting from flood problems and as a main source of water for construction. In addition, local people also use the water for different domestic and livestock consumptions and Catholic missionaries residing in Jigjiga town is also using water seeping through the dam for nursery to grow plant seedlings.

Due to lack of awareness among beneficiaries about irrigated agriculture and absence of strong and consistent support for the community, by GOs and NGOs, in order to disseminate such economic activities, this micro-dam have not been managed properly and utilized effectively. Today, in Ethiopia Somali Region the ground water is being used as main source of water for the residents. Elbahi micro-dam is also believed to play a significant role in recharging the ground water resource of the area. On the other hand, as the harvested water by Elbahi micro-dam was to supply water for domestic and livestock consumption for the community, its quality must be protected from different contaminants that harm human and livestock heath. However, due excessive soil erosion in the catchment area, that carries different poisonous chemicals, and reaches the reservoir by runoff, the quality of water in the reservoir has been deteriorating. Forest and bush clearing, complete removal of crop residue, overgrazing, poor soil management and land use practices exposed the soil 
to the intense rainfall characteristics of the area aggravate soil erosion in the area. The leading contributors for reducing water quality in the reservoir are use of fertilizers (like Urea and DAP) in the agricultural field increases levels of nitrogen and phosphorus in the runoff sediment loads that joins the reservoir.

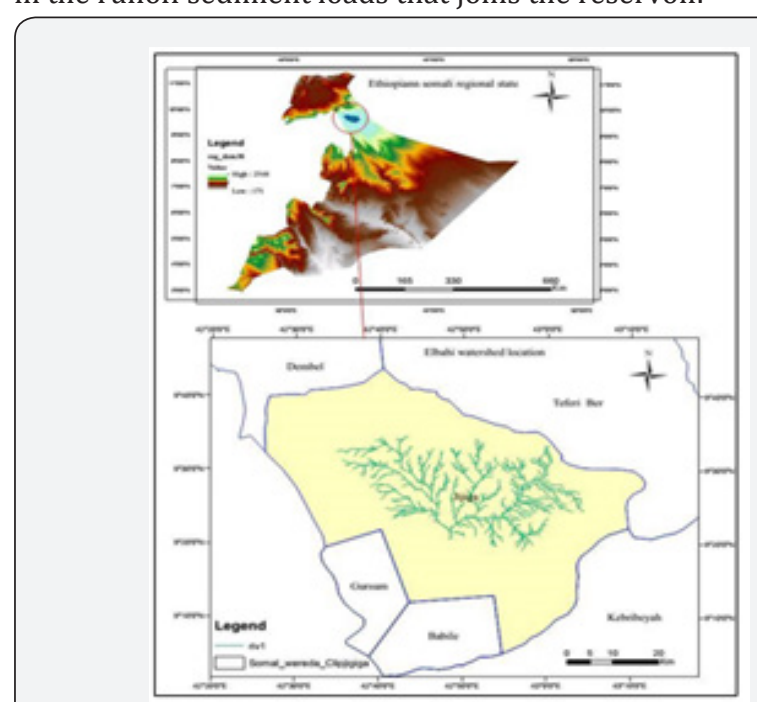

Figure 1: Location of Elbahi Micro-dam in Jigjiga woreda.

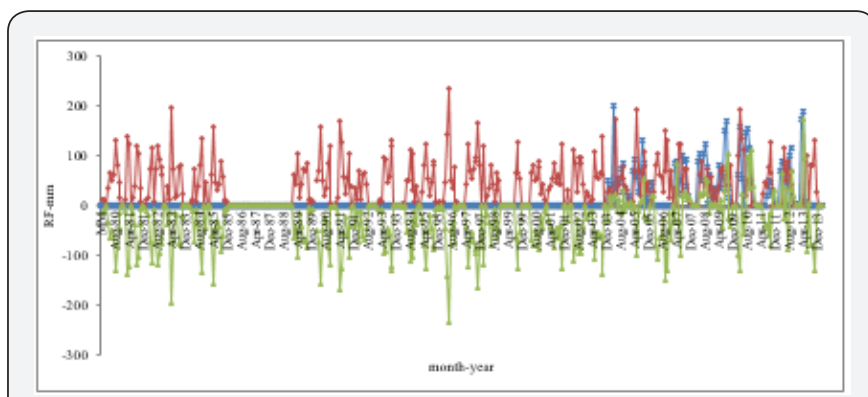

Figure 2: Daily rainfall condition in Elbeyih Micro-dam from 1980 to 2014 in $\mathrm{mm}$.

Sedimentation can also bring a decrease on the reservoir capacity of the dam, and the best example for such effects is Lake Haramaya [4]. Likewise, Elbahi micro-dam is suffering such problems due to intensive agricultural activities with poor soil and water management practices in the catchment. A like other parts of Somali Regional State of Ethiopia, Jigjiga town and areas in vicinity are suffering from shortage of water and its poor quality. It is easy to notice the scarce water resource of the area by observing the unreliable productivity of agricultural activities to provide sufficient crop production in the area. Shortage of domestic water supply, even in Jigjiga town shows how a strange condition existed in the area. Besides, there have been many activities to solve this problem. However, most of it is not successful. The best example for this statement is the Elbeyih micro-dam which is under a serious problem of sedimentation and its consequences. Since the date of its complete construction, the dam does not provide its proper service as required. Thus, investigating the existed problems that make the dam not to serve properly and intensify its purpose was very crucial [5]. Considering the importance of the issue in the Ethiopia Somali Region, an attempt was made to analysis of factors affecting the sustainability of Elbahi Micro- dam catchment, which is often needed for proper planning, management and designing of different types of water resource and conservation projects (Figure 1,2).

\section{Materials and Methods}

\section{Area description}

The study was conducted near to Jigjiga town, Eastern Ethiopia, the capital city of Ethiopia Somali Regional State. It is located $629 \mathrm{Km}$ far from Addis Ababa and approximately $80 \mathrm{~km}$ East of Harare and $60 \mathrm{~km}$ West of the border with Somalia, this town has a latitude and longitude of $9^{\circ} 21^{\prime} \mathrm{N}, 42^{\circ} 48^{\prime} \mathrm{E}$ with an elevation of around 1,610 meters above sea level. Based on the data obtained from the Central Statistical Agency [5], Jigjiga has an estimated total population of 98,076 of whom 50,355(51.34\%) are men and 47,721(48.66\%) are female. Four generic livelihood patterns are present in the zone (sedentary agriculture, agropastoralist, pastoralist and urban). Livestock, particularly cattle and camel are important integral components of rural livelihood systems in the zones. The study was conducted specifically on the Elbahi micro-dam watershed located near to Jigjiga town.

\section{Data and materials}

SWAT 2005 model was used to assess and to identify best land use measures suitable for the catchment. The DEM with $30 \mathrm{~m}$ resolution was used as an input to the SWAT model in order to delineate catchment area of the dam. Furthermore, the major input data required for this model includes a time series data; meteorological data (rainfall, temperature, relative humidity, wind speed, sunshine hour), land use land cover, and hydrologic data (i.e. river flow recorded along the stream in the catchment). Before accepting the output of the SWAT model, sensitivity analysis for different parameters and model calibration was conducted. Finally based on the result of model generated data, future use of the model for the research was realized. The model also enabled the analysis of historic land use land cover conditions in relation with stream flow, thus best land use management practices suitable for the area was identified.

GIS was used to install and run the SWAT model and to identify the meteorological stations from where data was collected, with the help of Theisson polygon method. Before all, a GPS was used to identify the actual geographic position of the dam, which is an input for the SWAT model to identify the outlet of the catchment. Before the meteorological and hydrologic data were fed in to selected hydrologic models, different statistical analyses were conducted to check for their consistency and homogeneity.

\section{Results and Discussion}

\section{Rainfall condition in the Elbahi Watershed}

The climatic condition of Elbahi micro-dam is mainly controlled by the seasonal migration of the Inter Tropical Convergence Zone (ITCZ), which is conditioned by the convergence of the trade winds of the northern and southern hemisphere and the associated atmospheric circulation. At local level and regional, it is also highly 


\section{International Journal of Environmental Sciences \& Natural Resources}

influenced, by the complex topography of the country. In March the ITCZ is located south of Ethiopia and moving northwards and in April it is located in southern Ethiopia. At $850 \mathrm{mb}$ level, there is strong low pressure cell over central Sudan. The anticyclone systems over Egypt and Arabia weaken; and another high pressure system develops over the Gulf of Aden and the Indian Ocean off the coast of Somalia. The Gulf of Aden-Indian Ocean high pressure system generates moist, easterly air currents over south eastern Ethiopia and southeasterly air currents along the Ethiopian Red Sea Coast. The tropical easterlies have therefore two components in Spring: the moist easterly and southeasterly air currents in eastern Ethiopia and the dry, northerly air currents in the north western quadrants of the country.

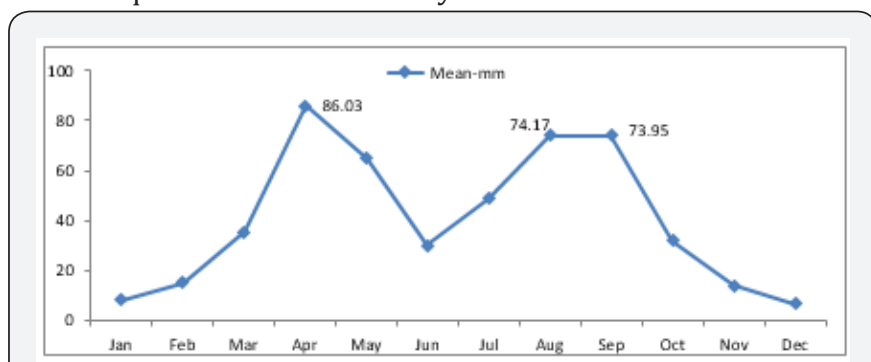

Figure 3: Mean Monthly Precipitation of Jigjiga station.

Table 1: Agro-ecological zone of Ethiopia Somali regions.

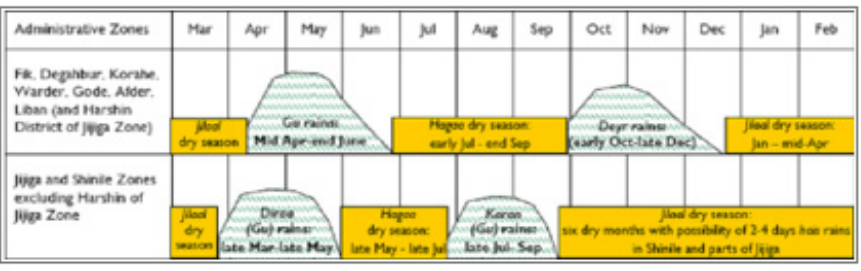

The Gulf of Aden-Indian Ocean moist air currents form a zone of convergence with the northerly air currents along the northern half of the western escarpment of the Ethiopian rift system. The easterly and the south-easterly moist air currents ascend over the highlands in spring produce the main rainy season in south eastern Ethiopia and bring the small rains of spring to most parts of the country, including the coast, excepting the north western quadrant of the country which is under the influence of the dry country northerly tropical easterlies. Therefore, all the climatic factors inherit these a fore mentioned characteristics [6]. Rainfall in Elbahi micro-dam catchment is generally characterized by high variability, and also erratic due to various factors mentioned above. The observations on rainfall distribution over the year are presented and the mean monthly amount of rainfall is indicated in the area of plot on (Figure 3). As observed from Figure 3, the Elbahi watershed has a bi-modal rainfall distribution that the area receives rainfall two times per year. However, the amount of rainfall received during these rainy periods is not similar. The larger amount of mean monthly precipitation of the area received during the main rainy season which extends from March to May while the second rainy season when lesser amount of mean monthly precipitation received extends from July to September (Figure 3) and (Table 1). Agro-ecological zone of Ethiopia Somali regions

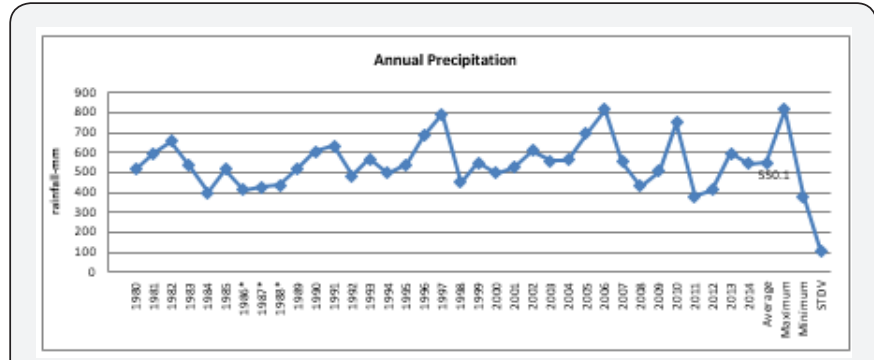

Figure 4: Averages mean annual rainfall of Jigjiga station.

The precipitation data analysis shows that the amount of mean annual received in the study area is $550.1 \mathrm{~mm}$. This average value of precipitation makes the area to have a dry Woyina-dega agro-ecological zone and hence, it indicates the possibility of semiarid agro-ecology adapted crop, tree and shrub species cultivation for various purposes. However, the occurrence of rainfall in the area has been very erratic. It is unpredictable and unreliable to ensure the productivity of traditional farming activities. On the other hand, such kind of precipitation is capable of eroding soil and causing different problems along with the ragged topography, poorly managed crops cultivation and open grazing with large livestock population available in the watershed area (Figure 4). The Elbahi micro-dam is located on this poorly managed watershed where the there is a high possibility and also indicating symptoms of large quantity of sediment movement towards the dam.

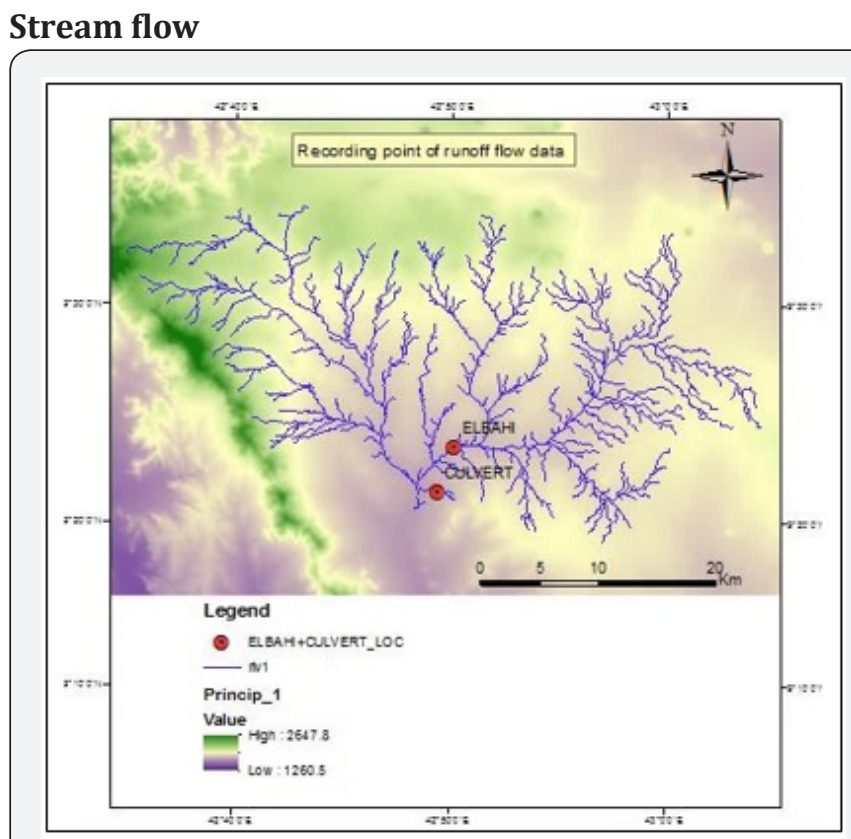

Figure 5: Location of the runoff stream flow recording point (Culvert).

To develop unit hydrograph to a catchment, detailed information about the rainfall and resulting flood hydrograph is needed. However, such information would be available only at a few locations and in a majority of catchments, especially those which are at remote locations; the data would normally very scanty. In order to construct unit hydrograph for such areas, empirical 
equations of regional validity which relate the salient hydrograph characteristics to the basin characteristics are available. Runoff flow of the watershed is not estimated exactly, because of absence of flow recording device in the area especially in the watershed site (Figure 5,6). But there is good news, near the dam location (far almost $2 \mathrm{~km}$-culverts) there is recording runoff flow data which is obtained from Ethiopian water resources agency, based on this an interpolation technique was used. Based on this fact, efforts made to develop a relationship between the under study watershed and near watershed using precipitation, runoff flow and catchment area as input parameters. Based on this interpolation technique, the result show from Jun-1999 to Sep-2014, even if this length of record data is not enough for hydro-statistical frequency analysis, but it can be used as a rough estimation.

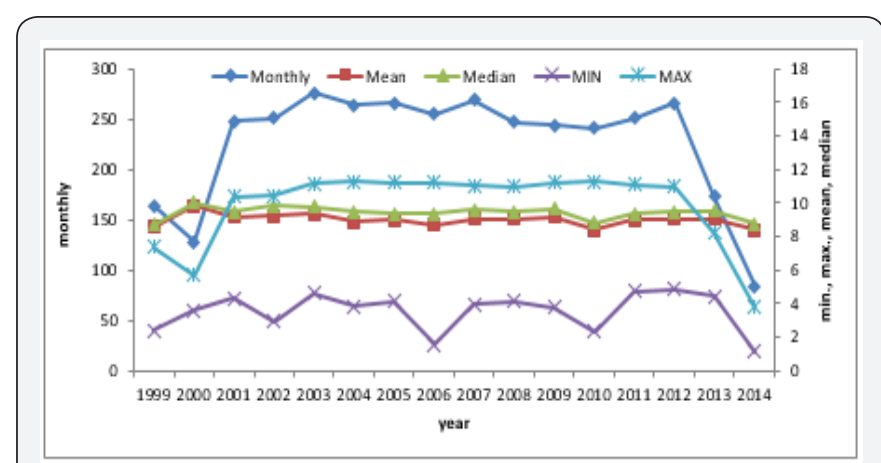

Figure 6: Annual flow of Toga River-the main stream of the Elbahi micro-dam watershed.

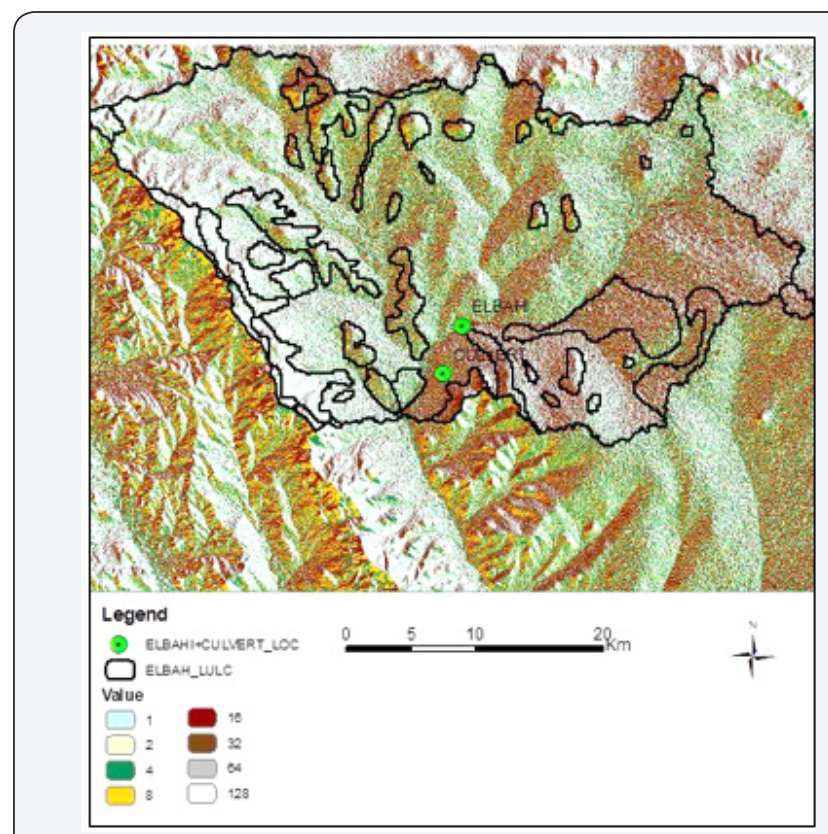

Figure 7: Flow direction of runoff developed by Arc GIS10.1.

Thus, the result obtained was enforced to relay on precipitation data and adopt recommended values of MoA (Ministry of Agriculture) for runoff coefficients of different land use land cover, soil and slope conditions. The result is indicted on (Figure 6) that the maximum recording was in 2012 and 2003, and the minimum record was in 2014 and 2000, and may be this show the ELINO phenomenon happed in 20115/16 was starting during time of 2014. As it can be seen from (Figure 7), the flow direction of the runoff to the outlet is from two sources. The first one is from Chinaksan watershed, while the other one is from the Elbahi dam watershed direction. Besides, these makes difficult to overcome with different techniques which try to solve the constraints, but the results obtained were not appreciable and unable to correlate the rainfall data with the stream flow records.

\section{Land use land cover}

Table 2: Land use land cover in Elbahi Micro-dam watershed.

\begin{tabular}{|c|c|c|}
\hline LC1-MASDES & Area in ha & Area in \% \\
\hline Shrub land; Dense (>50\% woody cover) & 20.23 & 1.87 \\
\hline Grassland; unstacked (woody plant) & 212.39 & 19.6 \\
\hline Bare land; Exposed rock & 14.45 & 1.33 \\
\hline $\begin{array}{c}\text { Cultivated Land; Rainfed; Cereal Land } \\
\text { Cover System; lightly stocked }\end{array}$ & 831.27 & 76.7 \\
\hline Urban & 5.44 & 0.5 \\
\hline Total & 1083.78 & 100 \\
\hline
\end{tabular}

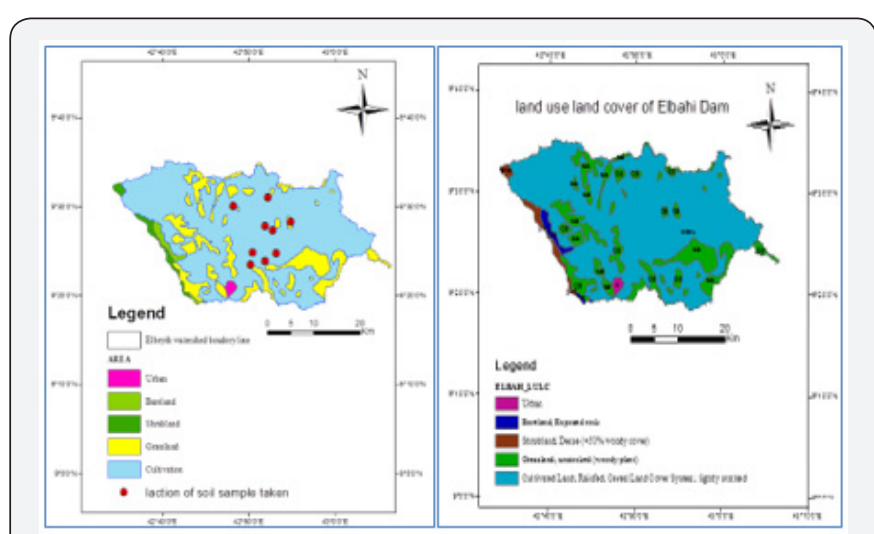

Figure 8: land use land cover of Elbahi Micro-dam watershed.

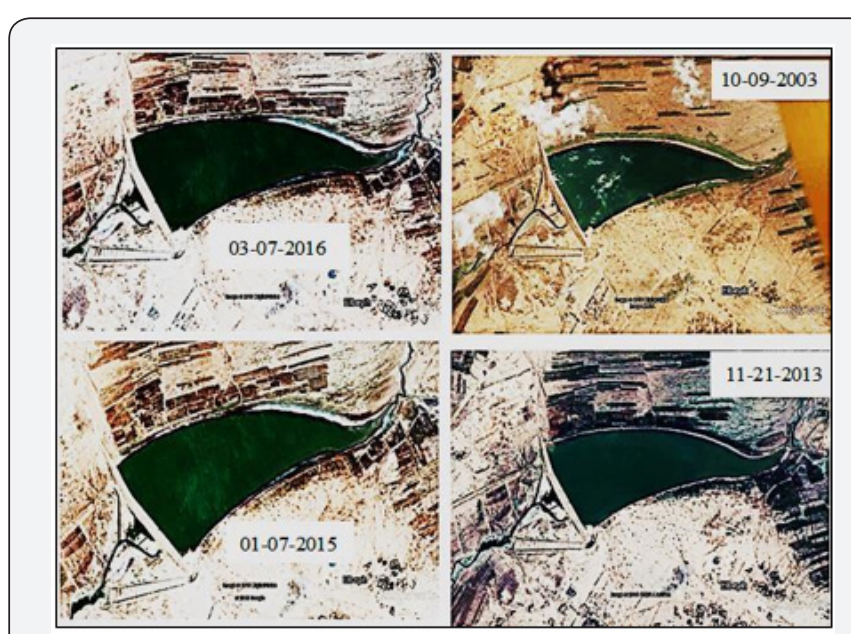

Figure 9: Images show land use change from 2003-2016.

With the use of Land use land cover map the description and understanding of the rainfall runoff processes in the area was made. A soil data collected from ground check points and an analysis made on a soil map obtained from Ministry of Water 
Resources and Energy (MoWREI), using Arc-GIS-10.1 application software, clarifies the area under this study was covered mainly by one type of land use which is cultivated land (76.7\%) with variable intensity, that varies significantly with local slope and elevation and its exposure history to erosion (Figure 8 and (Table 2). The analysis of this spatial data of land use and land cover of the study area shows the presence of five classes (shrub land, grass land, bare land, cultivated land and urban land) as shown in Table 2, and Figure 8. The land use land cover of the area constitutes a cultivation and grass land area where communal grazing is taking place. These land use land covers are responsible to aggravate runoff generation and soil erosion in the area. This day, the watershed area of the dam is occupied by new settlers in the area embedded by the expansion of community. Since the settlers are agro-pastoralists, large hectares of land are converted to cultivation and open grazing highly populated domestic animals. This would further intensify runoff generation in the area and enhance the severity of associated problems that have been endangering the hospitability of the watershed as general and, the Elbahi Micro-dam specifically during rainy seasons (Figure 9). The analysis also indicates that the erodibility coefficient $(\mathrm{K})$ value of the watershed is high, and this ascertains that the vulnerability of the soil to run-off erosion is very high. Consequently, the rapid sedimentation and reduction in the size and depth of the dam is observed.

\section{Soil classification in Elbahi Micro-Dam Watershed}

Table 3: FAO soil classification of Elbahi Micro-dam watershed.

\begin{tabular}{|c|c|c|c|c|c|c|c|}
\hline LC1-MASDES & LC1LU-DES & LANDUSE & LC1 & LC2 & & Area in ha & Area-\% \\
\hline Shrubland; Dense (>50\% woody cover) & Shrubland & RNGB & SHD & & & 20.23 & 1.87 \\
\hline Grassland; unstocked (woody plant) & Grassland & RNGE & GB & CRCB & 212.39 & 19.6 \\
\hline Bareland; Exposed rock & Bareland & URLD & TR & TS & 14.45 & 1.33 \\
\hline $\begin{array}{c}\text { Cultivated Land; Rainfed; Cereal Land Cover } \\
\text { System; lightly stocked }\end{array}$ & Cultivation & AGRL & CRCL & GB & & 831.27 \\
\hline Urban & Urban & URHD & U & & & 5.44 & 0.5 \\
\hline & & & & Total & 1083.78 & & 100 \\
\hline
\end{tabular}

\begin{tabular}{|c|c|c|c|}
\hline Soil-Type & Shape-Leng & Shape-Area & Area in \% \\
\hline Dystric nitisols & 210.23 & 523.41 & 48.267 \\
\hline Vertic cambisols & 218.96 & 546.14 & 50.363 \\
\hline Chromic luvisols & 23.21 & 14.87 & 1.372 \\
\hline Total & 452.40 & 1084.42 & EVRl \\
\hline
\end{tabular}

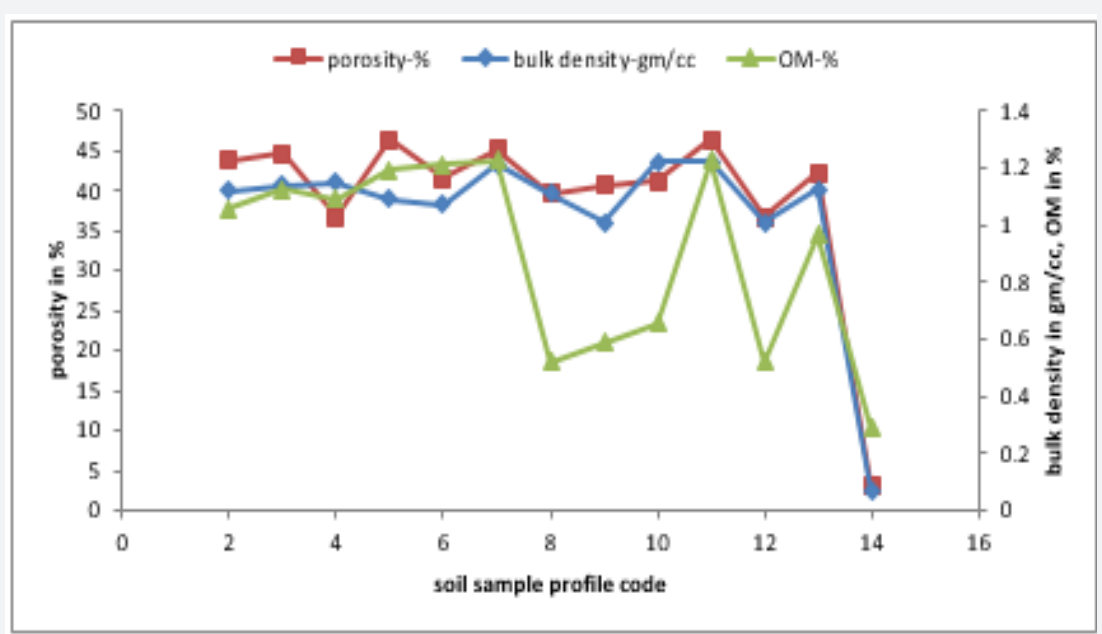

Figure 10: Physical properties of Elbahi Micro-dam watershed.

The major soil classes found in the Elbahi dam watershed (Figure 10) and (Table 3) are Dystric nitisols (48\%), Vertic cambisols (50\%) and chromic luvisols (2\%), which affect soil degradation differently [7]. Soils vary in their resistance to erosion partly based on texture and amount of organic matter. The resistance also depends on soil condition and depth. Soils high in silt and low in clay and sand are highly erodible [8]. High erodibility of silty soils is explained by their weak structural stability. They rapidly form surface seals upon the impact of rain drops. Erosion is less on clayey soils due to better aggregation and on sandy soils due to the non-sealing surface (Figure 11). Slope aspect and orientation in Elbahi Micro-dam watershed Based on 
the digital elevation model the range of elevation difference in the area, slope and slope aspect and orientation were analyzed. Consequently, the range of slope in the area dominantly four scale ranges as 0-5 \%-upper part of the watershed which shews gentle and flat slope, 6-10\% at different part of the watershed, 11$20 \%$ and $21-30 \%$ in the lower part of the watershed to the left side (Chenaksen catchment) of the catchment (Figure 12,13). In addition, this, Arc-GIS-10.1 software is used to classify the contour of the watershed as required $[9,10]$.

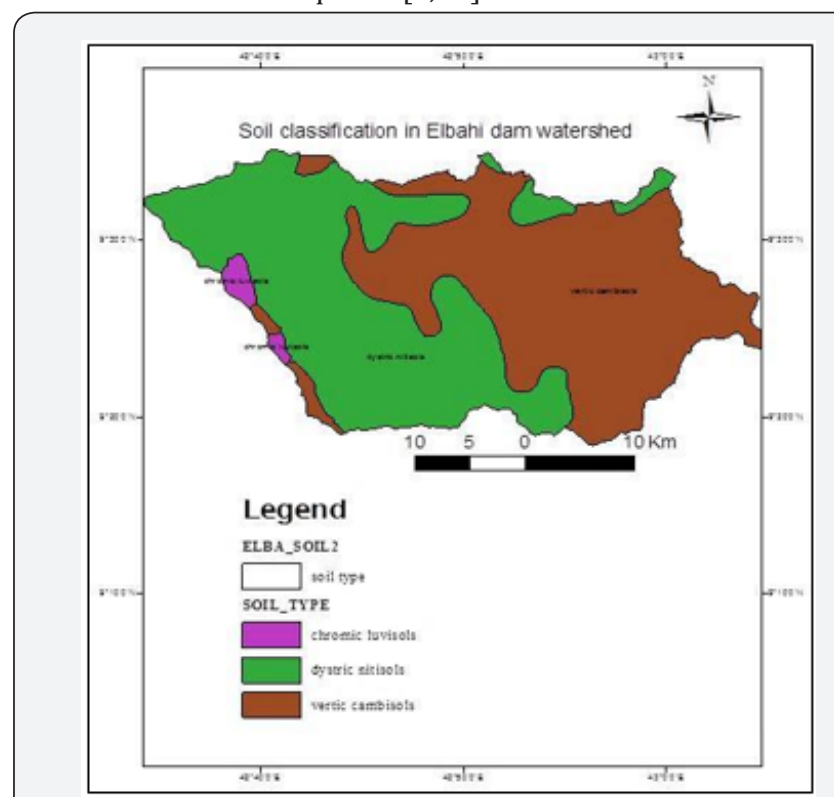

Figure 11: FAO soil classification of Elbahi Micro-dam watershed.

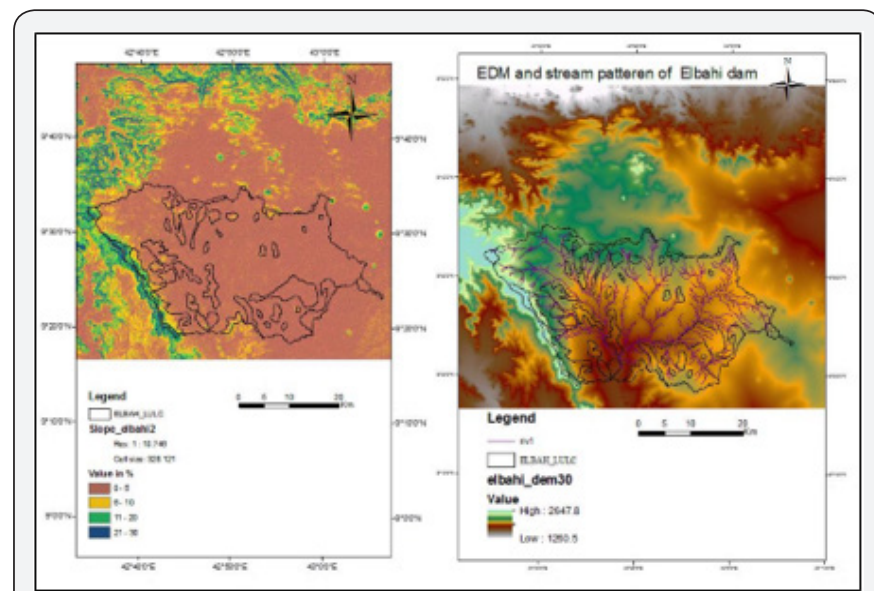

Figure 12: Slope classification and stream pattern of Elbahi Micro-dam watershed.

\section{Acknowledgement}

My deepest and unreserved thanks to Jigjiga University, Research and Technology Transfer Directorate for giving us the chance, and for their financial support, and to Adigrat University, Aksum University and Woliata Sodo Universities which are currently employ us. Thanks, are also to Ethiopian National Meteorology Service Agency Addis Ababa head office and Jigjiga regional branch and Ministry of Water Resources and Energy (MoWRE), for their affordance of meteorological and runoff recorded data.

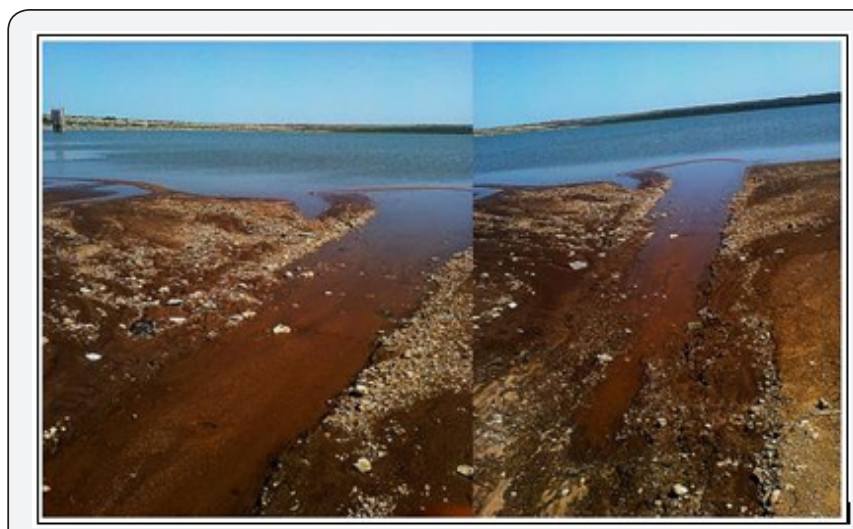

Figure 13: Sedimentation process in the mouth of the Elbeyih dam.

\section{References}

1. Gleick PH (1993) Water in Crisis. Oxford University Press, New York, USA.

2. Kundzewicz ZW (1997) Water resources for sustainable development. Hydrological Sciences Journal-des Sciences Hydrologic 42(4): 467480 .

3. Vorosmarty CJ, Green P, Salisbury J, Lammers RB (2000) Global water resources: vulnerability from climate change and population growth. Science 238: 284-288.

4. Mulugeta S, Yohannes F, Rashid SM (2006) Soil erosion assessment of lake Alemaya catchment, Ethiopia. Land Degrade Develop 17(3): 333341.

5. Foster GR, Lane LJ (1981) Simulation of erosion and sediment yield from field-sized areas. In Tropical agricultural hydrology, ed R Lal and EW Russell. Chichester, Wiley pp. 375-394.

6. CSA (2005) Central Statistical Authority of Ethiopian, Addis Ababa, Ethiopia.

7. Cho VT, Maidment, LW Mays (1988) Applied Hydrology, McGraw Hill, Inc.

8. OESPO (1999) Agricultural sector study: Soil resources in Oromiya. Draft, final Report, Oromiya Economic Study Project Office.

9. Nill D, Schwertmann U, Sabel Koschella U, Bernard M, Breuer J (1996) Soil Erosion by Water in Africa Principles, Prediction and Protection. Rossdorf, Germany TZ Verlagsgesellschaft.

10. (2004) SCUK/DPP. Final Report of Terminal Evaluation of Emergency Nutrition Intervention Program in Shashego and Hulbareg woredas of the SNNPR, Ethiopia. 
Your next submission with Juniper Publishers will reach you the below assets

- Quality Editorial service

- Swift Peer Review

- Reprints availability

- E-prints Service

- Manuscript Podcast for convenient understanding

- Global attainment for your research

- Manuscript accessibility in different formats ( Pdf, E-pub, Full Text, Audio)

- Unceasing customer service

Track the below URL for one-step submission https://juniperpublishers.com/online-submission.php 